\title{
EVALUASI PROFESIONALISME GURU
}

\author{
B a s r i, M.Pd \\ Dosen FKIP UNIGHA SIGLI \\ Email: basri6609@gmail.com
}

\begin{abstract}
ABSTRAK
Guru profesional dituntut memiliki seperangkat kemampuan kompetensi guru. Dalam UndangUndang Guru dan Dosen No. 14 Tahun 2005 dan Peraturan Pemerintah No. 19 Tahun 2005 dinyatakan bahwa kompetensi guru meliputi kompetensi kepribadian, kompetensi pedagogik, kompetensi profesional dan kompetensi sosial. Berlakunya undang-undang dan peraturan tersebut menuntut para guru untuk meningkatkan profesionalisme. Kinerja guru dapat dilihat dari rasa tanggung jawab menjalankan tugas profesinya akan memegang tanggung jawab moral. Semua Ini akan terlihat dalam kepatuhan dan loyalitas dalam menjalankan tugas kependidikannya di kelas dan di luar kelas. Tiga komponen untuk penilaian kinerja guru secara teknis, yaitu (1) mengamati kelas (observasi Kelas), (2) memeriksa program kerja, khususnya RPP, dan (3) melakukan validasi data melalui triangulasi. Kinerja profesional juga dapat dilihat dari aspek peningkatan kualitas (1) belajar dengan memberdayakan berbagai aspek; (2) penguasaan, aplikasi, dan produk Ilmu pengetahuan dan teknologi, seperti menulis buku, karya ilmiah, penelitian, membuat alat peraga, penerapan teknologi; (3) kontribusi guru dalam pekerjaan; (4) pelaksanaan strategi atau teknologi baru dalam belajar seperti e-learning, lesson study, pembelajaran kuantum, konstruktivisme; (5) memanfaatkan teknologi informasi sebagai sarana pembelajaran seperti internet; dan (6) motivasi terus berkembang untuk kemajuan dan kualitas pembelajaran, administrasi, pengembangan diri, yang menyebabkan perbaikan dan peningkatan kualitas pembelajaran.
\end{abstract}

Kata kunci: Evaluasi dan Profesionalisme Guru.

\section{PENDAHULUAN}

Dalam upaya peningkatan mutu pendidikan, aspek utama yang ditentukan adalah kualitas guru. Hal ini disebabkan guru merupakan titik sentral dalam pembaharuan dan peningkatan mutu pendidikan, dengan kata lain salah satu persyaratan penting bagi peningkatan mutu pendidikan adalah apabila pelaksanaan proses belajar mengajar dilakukan oleh pendidik-pendidik yang dapat diandalkan keprofesionalannya.

Usaha Pemerintah untuk mendorong peningkatkan mutu pendidikan, salah satunya adalah untuk meningkatkan kualitas guru. karena kualitas sistem pendidikan secara keseluruhan erat kaitannya dengan kualitas guru. Guru memiliki peran strategis dalam pendidikan, bahkan sumber pendidikan lainnya yang cukup sering kurang berarti bila tidak didukung oleh adanya guru yang berkualitas. Guru mempunyai peranan yang strategis dalam upaya untuk meningkatkan kualitas layanan dan hasil pendidikan. Guru merupakan kunci utama dalam upaya meningkatkan kualitas pendidikan. Oleh karena itu, sangat wajar jika akhir-akhir ini pengakuan dan penghormatan terhadap profesi guru telah meningkat, yang dimulai dengan telah Undang-Undang Nomor 14 Tahun 2005, tentang guru dan dosen.

Guru adalah jabatan profesi sehingga guru harus mampu melakukan pekerjaan mereka secara profesional. Seseorang dianggap professional ketika mampu bekerja pada tugastugas dengan selalu berpegang teguh pada etika profesi, independen, produktif, efektif, efisien dan inovatif dan didasarkan pada prinsipprinsip pelayanan prima yang didasarkan pada unsur-unsur ilmu atau teori sistematis, otoritas profesional, pengakuan masyarakat, dan kode etik yang regulatif.

Guru profesional memiliki tugas utama pendidikan, mengajar, membimbing, mengarahkan, melatih, menilai, dan mengevaluasi peserta didik pada pendidikan anak usia dini jalur pendidikan formal, pendidikan dasar, dan pendidikan menengah. Dalam melaksanakan tugasnya, guru menerapkan keahlian, kemampuan yang memenuhi standar kualitas tertentu atau norma diperoleh melalui pendidikan profesi.

Urusan tambahan yang terkait dengan tugas sebagai guru yang ditugaskan dengan 
prinsip-prinsip penghargaan atas dasar prestasi. Hal ini sesuai dengan tujuan sertifikasi diadakannya untuk guru, yaitu: (1) menentukan kelayakan seseorang dalam melaksanakan tugas sebagai agen pembelajaran; (2) peningkatan kualitas proses dan hasil pendidikan; dan (3) peningkatan profesionalisme guru (Dikti, 2006).

Sesuai amanat undang-undang Republik Indonesia Nomor 20 Pada tahun 2003 tentang Sistem Pendidikan Nasional, yang menyebutkan bahwa jabatan guru sebagai pendidik adalah jabatan Professional. Untuk itu, guru profesional dituntut untuk terus berkembang sesuai dengan perkembangan ilmu pengetahuan dan teknologi, serta kebutuhan masyarakat untuk meningkatkan sumber daya manusia yang berkualitas dan memiliki kemampuan agar dapat bersaing dalam forum regional, nasional, maupun internasional. Sesuai dengan regulasi pemerintah dalam undang-undang Nomor 14 tahun 2005 tentang guru dan dosen.

\section{KARAKTERISTIK PROFESIONALISME GURU}

Karakteristik guru profesionalisme menurut Orstein dan Levine (Rahmat Wahab, 2009) menegaskan bahwa pada pada dasarnya pekerjaan mengajar dapat dikategorikan menjadi tiga tingkatan, yaitu mengajar sebagai semi-profession, emerging profession, dan full profession.

Pertama, mengajar dikatakan semi profesional, ketika profesi mengajar hanya disiapkan melalui pelatihan jangka pendek, bahkan mengajar dapat dilakukan oleh siapa saja yang mengaku pernah diajarkan, karena profesi mengajar dilakukan dengan hanya meniru saja yang dilakukan oleh guru, tanpa dilalui proses latihan. Kedua, mengajar dikatakan emerging profession yang mana di satu sisi mengajar dianggap sebagai profesi, namun di sisi lain profesi dipersiapkan sesuai dengan kebutuhan. Selain itu, mengajar adalah pekerjaan yang menuntut penyesuaian terus menerus, bersama dengan perubahan tuntutan masyarakat yang terus berkembang, sehingga guru harus terus-menerus melakukan updating penguasaan materi keilmuannya, dan metode pembelajaran yang kreatif dan inovatif.

Ketiga, profesi guru dikatakan full profession, karena mengajar adalah profesi, yaitu guru harus memiliki pengetahuan tertentu dan dapat berguna bagi masyarakat dan dapat memberi solusi terhadap permasalahan pendidikan.

McNergney dan Joanne (Rahmat Wahab, 2009) Menyatakan bahwa mengajar sebagai profesi menuntut sejumlah karakteristik sebagai berikut:

1. Rasa melayani masyarakat adalah komitmen dari seluruh waktu karirnya.

2. Pengetahuan dan keterampilan yang pada kemampuan atas manusia pada umumnya.

3. Penerapan penelitian dan teori dalam praktek, berkaitan dengan masalah kemanusiaan.

4. Membutuhkan waktu yang panjang untuk latihan spesialisasinya.

5. Adanya kontrol terhadap standar lisensi dan persyaratan masuk.

6. Memiliki otonomi dalam membuat keputusan terkait dengan bidang kerja profesinya.

7. Berani menerima tanggung jawab mengenai penilaian dibuat dan tindakan dilakukan dalam memberikan layanan.

8. Komitmen untuk profesi dan klien, ditandai dengan penekanan dengan layanan yang diberikan.

9. Memiliki organisasi yang bersifat otonom, yang keanggotaannya seprofesi.

10. Memiliki Asosiasi Profesi

11. Memiliki kode etik, yang membantu untuk mengklarifkasi permasalahan yang timbul sehubungan dengan layanan yang diberikan.

12. Memiliki prestise dan penghargaan ekonomik yang tinggi.

Di antara karaketeristik-karakteristik di atas, maka yang dianggap sangat penting adalah: (1) memiliki pengetahuan dan keterampilan yang berkaitan dengan bidang profesinya di atas kemampuan manusia pada umumnya; (2) adanya kontrol terhadap standar lisensi dan persyaratan masuk untuk menjadi guru; (3) memiliki otonomi dalam membuat keputusan yang berkaitan dengan bidang profesinya; dan (4) memiliki prestise dan penghargaan ekonomik yang tinggi.

Profesi guru dan dosen merupakan bidang pekerjaan khusus yang memerlukan prinsip-prinsip profesional. Yaitu (1) memiliki bakat, minat, panggilan jiwa, dan idealisme, (2) memiliki kualifikasi pendidikan dan latar belakang pendidikan yang sesuai dengan bidang tugas, (3) memiliki kompetensi yang diperlukan sesuai dengan bidang tugas (4) 
mematuhi kode etik profesi, (5) memiliki hak dan kewajiban dalam pelaksanaan tugas, (6) memperoleh penghasilan yang ditentukan sesuai dengan prestasi kerjanya, (7) memiliki kesempatan untuk mengembangkan profesinya secara berkelanjutan, (8) memperoleh perlindungan hukum dalam melaksanakan tugas Profesional, dan (9) dan memiliki organisasi profesi yang berlandaskan hukum (UU No. 14/2005, tentang guru dan Dosen)

Hasan (2009), mengemukakan guru profesional Indonesia memiliki; (1) dasar ilmu yang kuat sebagai perwujudan teknologi terhadap masyarakat dan ilmu pengetahuan masyarakat di abad ke-21; (2) penguasaan taktik profesi berdasarkan penelitian dan Praksis pendidikan yang dalam ilmu pendidikan sebagai praksis bukan hanya konsep belaka. Pendidikan merupakan proses yang terjadi di lapangan dan bersifat ilmiah, serta penelitian pendidikan harus diarahkan pada pendidikan praksis masyarakat Indonesia; (3) pengembangan kemampuan profesional berkelanjutan, profesi guru adalah profesi yang berkembang terus-menerus dan berkelanjutan antara LPTK dengan praktek pendidikan. Menghambat profesi guru dan ilmu Program pendidikan pra-universitas menyebabkan pemutusan layanan dan in-service karena pertimbangan dari manajemen pendidikan kaku atau birokrasi lemah. Kekerdilan profesi guru dan ilmu pendidikan disebabkan terputusnya program pre-service dan in-service karenapertimbangan birokratis yang kaku atau manajemen pendidikan yang lemah.

Dari beberapa upaya Pemerintah telah dilakukan di atas, faktor-faktor yang yang paling penting agar guru dapat meningkatkan kualifikasi dirinya dengan menyetarakan jumlah jam mengajar dengan gaji guru. Program apapun yang akan diterapkan pemerintah tetapi jika gaji guru rendah, untuk memenuhi kebutuhan hidup guru akan mencari pekerjaan tambahan untuk mencukupi kebutuhannya. Tak heran jika para guru di negara maju kualitas tinggi atau dikatakan profesional, karena apresiasi jasa para guru sangat tinggi. Di Inggris Raya dan Wales untuk meningkatkan profesionalisme guru pemerintah mulai memperhatikan pembayaran gaji guru yang seimbang dengan beban kerja. Di Amerika Serikat itu sudah berlaku, jadi jangan heran jika pendidikan yang berlaku di Amerika Serikat menjadi pola negara-negara ketiga

(http://researchengines.com/amhasan.html)

Guru dikondisikan pada posisi garda terdepan dan sangat sentral dalam pelaksanaan proses pembelajaran termasuk proses ujian. Guru profesional dituntut untuk memiliki kode etik, yaitu norma tertentu sebagai pegangan yang diakui dan dihargai oleh masyarakat. Kode etik adalah landasan moral dan pedoman perilaku utama dengan sikap para anggota. guru memiliki otonomi khusus dapat mengatur diri mereka sendiri, memiliki sikap mandiri dalam melaksanakan tugas. Guru membuat keputusan dan bertanggung jawab keputusan (Jatmiko, 2008)

Guru profesional memiliki lima kualifikasi (a) akademik , (b) kompetensi, (c) sertifikat, (d) kesehatan lahir dan batin, dan (e) merealisasikan tujuan pendidikan (Joni, 2008a). Secara khusus Joni (2008b) menyebutkan Empat Pilar pembelajaran lepaskonteks itu menjadi (a) kompetensi pedagogik, (b) kompetensi kepribadian (C), kompetensi profesional, dan (d) kompetensi sosial.

Guru profesional mendukung penjaminan kualitas secara berkelanjutan. Profesionalisasi harus dilihat sebagai proses yang berkesinambungan. Dalam proses ini, pendidikan Prajabatan, termasuk di Kantor pendidikan penataran, pembinaan dari organisasi profesi dan penghargaan kerja masyarakat terhadap profesi keguruan, penegakan kode etik profesi, sertifikasi, peningkatan kualitas calon guru, imbalan, dll secara bersama-sama menentukan pengembangan profesionalisme seseorang termasuk guru.

\section{KOMPETENSI GURU}

Kinerja guru mempunyai spesifikasi/kriteria tertentu. Kinerja guru da-pat dilihat dan diukur berdasarkan spesifikasi/kriteria kompetensi yang harus dimiliki oleh setiap guru.

Berdasarkan Peraturan Menteri Pendidikan Nasional Republik Indone-sia Nomor 16 Tahun 2007 tentang Standar Kualifikasi Akademik dan Kompetensi Guru. Dijelaskan bahwa Standar Kompetensi Guru dikembangkan secara utuh dari 4 kompetensi utama, yaitu: (1) kompetensi pedagogik, (2) kepribadian, (3) sosial, dan (4) profesional. Keempat kompetensi tersebut terin-tegrasi dalam kinerja guru.

1. Kompetensi Pedagogik 
Kompetensi pedagogik yaitu kemampuan yang harus dimiliki guru berkenaan dengan karakteristik siswa dilihat dari berbagai aspek seperti moral, emosional, dan intelektual. Hal tersebut berimplikasi bahwa seorang guru harus mampu menguasai teori belajar dan prinsip-prinsip belajar, karena siswa memiliki karakter, sifat, dan interest yang berbeda. Berkenaan dengan pelaksanaan kurikulum, seorang guru harus mampu mengembangkan kurikulum tingkat satuan pendidikan masing-masing dan disesuaikan dengan kebutuhan lokal. Guru harus mampu mengoptimalkan potensi peserta didik untuk meng-aktualisasikan kemampuannya di kelas, dan harus mampu melakukan kegiatan penilaian terhadap kegiatan pembelajaran yang telah dilakukan.

Kemampuan yang harus dimiliki guru berkenaan dengan aspek-aspek yang diamati, yaitu:

a. Penguasaan terhadap karakteristik peserta didik dari aspek fisik, moral, sosial, kultural, emosional dan intelektual.

b. Penguasaan terhadap teori belajar dan prinsip-prinsip pembelajaran yang mendidik.

c. Mampu mengembangkan kurikulum yang terkait dengan bidang pengembangan yang diampu.

d. Menyelenggarakankegiatanpengembanga $n$ yang mendidik.

e. Memanfaatkan teknologi informasi dan komunikasi untuk kepentingan penyelenggaraan kegiatan pengembangan yang mendidik.

f. Memfasilitasi pengembangan potensi peserta didik untuk mengaktualisasikan berbagai potensi yang dimiliki.

g. Berkomunikasi secara efektif, empatik, dan santun dengan peserta didik.

h. Melakukan penilaian dan evaluasi proses dan hasil belajar, memanfaatkan hasil penilaian dan evaluasi untuk kepentingan pembelajaran.

i. Melakukan tindakan reflektif untuk peningkatan kualitas pembelajaran.

\section{Kompetensi Kepribadian}

Pelaksanaan tugas sebagai guru harus didukung oleh suatu perasaan bangga akan tugas yang dipercayakan kepadanya untuk mempersiapkan generasi kualitas masa depan bangsa. Walaupun berat tantangan dan rintangan yang dihadapi dalam pelaksanaan tugasnya harus tetap tegar dalam melaksa-kan tugas sebagai seorang guru.

Pendidikan adalah proses yang direncanakan agar semua berkembang melalui proses pembelajaran. Guru sebagai pendidik harus dapat mempenga-ruhi ke arah proses itu sesuai dengan tata nilai yang dianggap baik dan berla-ku dalam masyarakat.

Tata nilai termasuk norma, moral, estetika, dan ilmu pengetahuan, mempengaruhi perilaku etik siswa sebagai pribadi dan sebagai anggota masyara-kat. Penerapan disiplin yang baik dalam proses pendidikan akan menghasilkan sikap mental, watak dan kepribadian siswa yang kuat. Guru dituntut harus mampu membelajarkan siswanya tentang disiplin diri, belajar membaca, mencintai buku, menghargai waktu, belajar bagaimana cara belajar, mematuhi aturan/tata tertib, dan belajar bagaimana harus berbuat. Semuanya itu akan berhasil apabila guru juga disiplin dalam melaksanakan tugas dan kewajibannya.

Guru harus mempunyai kemampuan yang berkaitan dengan kemantapan dan integritas kepribadian seorang guru. Aspekaspek yang diamati adalah:

a. Bertindak sesuai dengan norma agama, hukum, sosial, dan kebudayaan nasional Indonesia.

b. Menampilkan diri sebagai pribadi yang jujur, berakhlak mulia, dan te-ladan bagi peserta didik dan masyarakat.

c. Menampilkan diri sebagai pribadi yang mantap, stabil, dewasa, arif, dan berwibawa.

d. Menunjukan etos kerja, tanggung jawab yang tinggi, rasa bangga menjadi guru, dan rasa percaya diri.

e. Menjunjung tinggi kode etik profesi guru.

3. Kompetensi Sosial

Guru di mata masyarakat dan siswa merupakan panutan yang perlu di-contoh dan merupkan suritauladan dalam kehidupanya sehari-hari. Guru perlu memiliki kemampuan sosial dengan masyakat, dalam rangka pelaksanaan proses pembelajaran yang efektif. Dengan dimilikinnya kemampuan tersebut, otomatis hubungan sekolah dengan masyarakat akan berjalan dengan lancar, sehingga jika ada keperluan dengan orang tua siswa, para guru tidak akan mendapat kesulitan.

Kemampuan sosial meliputi kemampuan guru dalam berkomunikasi, bekerja sama, bergaul simpatik, dan mempunyai jiwa yang menyenangkan. 
Kriteria kinerja guru yang harus dilakukan adalah:

a. Bertindak objektif serta tidak diskriminatif karena pertimbangan jenis kelamin, agama, ras, kondisi fisik, latar belakang keluarga, dan status sosial ekonomi.

b. Berkomunikasi secara efektif, empatik, dan santun dengan sesama pendidik, tenaga kependidikan, orang tua, dan masyarakat.

c. Beradaptasi di tempat bertugas di seluruh wilayah Republik Indonesia yang memiliki keragaman sosial budaya.

d. Berkomunikasi dengan komunitas profesi sendiri dan profesi lain secara lisan dan tulisan atau bentuk lain.

\section{Kompetensi Profesional}

Kompetensi Profesional yaitu kemampuan yang harus dimiliki guru dalam perencanaan dan pelaksanaan proses pembelajaran. Guru mempunyai tugas untuk mengarahkan kegiatan belajar siswa untuk mencapai tujuan pem-belajaran, untuk itu guru dituntut mampu menyampaikan bahan pelajaran. Guru harus selalu meng-update, dan menguasai materi pelajaran yang disajikan. Persiapan diri tentang materi diusahakan dengan jalan mencari informasi melalui berbagai sumber seperti membaca buku-buku terbaru, mengakses dari internet, selalu mengikuti perkembangan dan kemajuan terakhir tentang materi yang disajikan.

Kompetensi atau kemampuan kepribadian yaitu kemampuan yang harus dimiliki guru berkenaan dengan aspek:

a. Dalam menyampaikan pembelajaran, guru mempunyai peranan dan tugas sebagai sumber materi yang tidak pernah kering dalam mengelola proses pembelajaran. Kegiatan mengajarnya harus disambut oleh siswa sebagai suatu seni pengelolaan proses pembelajaran yang diperoleh melalui latihan, pengalaman, dan kemauan belajar yang tidak pernah putus.

b. Dalam melaksakan proses pembelajaran, keaktifan siswa harus selalu diciptakan dan berjalan terus dengan menggunakan metode dan strategi mengajar yang tepat. Guru menciptakan suasana yang dapat mendorong siswa untuk bertanya, mengamati, mengadakan eksperimen, serta menemu-kan fakta dan konsep yang benar. Karena itu guru harus melakukan kegi-atan pembelajaran menggunakan multimedia, sehingga terjadi suasana belajar sambil bekerja, belajar sambil mendengar, dan belajar sambil bermain, sesuai kontek materinya.

c. Di dalam pelaksanaan proses pembelajaran, guru harus memperhatikan prinsip-prinsip didaktik metodik sebagai ilmu keguruan. Misalnya bagaimana menerapkan prinsip apersepsi, perhatian, kerja kelompok, korelasi dan prinsip-prinsip lainnya.

d. Dalam hal evaluasi, secara teori dan praktik, guru harus dapat melaksana-kan sesuai dengan tujuan yang ingin diukurnya. Jenis tes yang digunakan untuk mengukur hasil belajar harus benar dan tepat. Diharapkan pula guru dapat menyusun butir secara benar, agar tes yang digunakan dapat me-motivasi siswa belajar.

Kemampuan yang harus dimiliki guru dalam proses pembelajaran dapat diamati dari aspek-aspek:

a. Menguasai materi, struktur, konsep, dan pola pikir keilmuan yang mendu-kung mata pelajaran yang diampu.

b. Menguasai Standar Kompetensi dan Kompetensi Dasar mata pelajaran/ bidang pengembangan yang diampu.

c. Mengembangkan materi pelajaran yang diampu secara kreatif.

d. Mengembangkan keprofesionalan secara berkelanjutan dengan melakukan tindakan reflektif

e. Memanfaatkan teknologi informasi dan komunikasi untuk berkomunikasi dan mengembangkan diri

\section{EVALUASI KINERJA GURU}

Agar kinerja guru dapat ditingkatkan dan memberi sumbangan mungkin terhadap siswa dan sekolah secara keseluruhan, maka perlu dilakukan evaluasi kinerja guru. Ronald T.C. Boyd (Akhmad Sudrajad, 2008b) menunjukkan bahwa evaluasi kinerja guru didesain untuk melayani dua tujuan, yaitu: (1) untuk mengukur kompetensi guru dan (2) mendukung pengembangan Profesional. Oleh karena itu, sistem evaluasi kinerja guru harus memberikan manfaat sebagai umpan balik untuk memenuhi berbagai kebutuhan di kelas (classroom needs), dan dapat memberikan kesempatan untuk pengembangan sekolah dan guru itu sendiri. 
Menurut Robert Bacal (Akhmad Sudrajad, 2008a) penilaian atau evaluasi kinerja merupakan bagian dari manajemen kinerja (performance Manajemen) itu sendiri. Menurut Robert Bacal (Akhmad Sudrajad, 2008a), manajemen kinerja guru adalah proses komunikasi yang keberlanjutan dan dilakukan dalam kemitraan antara guru dengan atasan, atasan, atau penilainnya. Proses ini meliputi kegiatan membangun Kesepakatan dan pemahaman mengenai tuntutan yang ada, baik yang terkait dengan tanggung jawab terhadap keberhasilan siswa, guru, dan keberhasilan sekolah dengan dirinya sendiri.

Untuk menilai kinerja guru diperlukan standar baku. Dalam praktek standar untuk penilaian kinerja guru yang baik dapat dicoba kesepakatan para pihak yang akan menilai (kepala sekolah) dan guru yang akan dinilai (Agus Sumarno, 2008). Namun, dalam konteks kinerja guru Profesional, maka indikator pendukungnya harus didasarkan pada standar yang ada. Di India, pakar (Advancement of Educational Performance through Teacher Support) adalah sebuah program peningkatan kinerja guru, yang didukung oleh UNICEF, telah menggunakan aspek kinerja guru di kelas sebagai salah satu standar utama guru berkinerja baik (Shukla Subir, 2008). Lebih lanjut menyatakan, bahwa untuk menilai kinerja guru, ADEPTS menerapkan kegiatan on service, yaitu sebuah program peningkatan kinerja guru di kelas dan penilaian yang diterapkan. penilaian ini bukan untuk pembenaran kemampuan, melainkan menjadi masukan untuk perbaikan kinerja guru secara bertahap dan progresif (Subir Shukla, 2008).

Di Indonesia, di era sertifikasi guru, standar untuk mengukur kinerja guru kompetensi profesional adalah empat kompetensi guru (atau standar keprofesionalan guru), yang menunjukkan seluruh sosok guru profesional (T. Raka Joni, 2008) menyebutkan bahwa seorang guru yang kompeten, harus memiliki (1) pemahaman tentang karakteristik peserta didik, (2) penguasaan bidang studi, baik dari lembaga ilmiah atau pendidikan, (3) kemampuan Organisasi belajar yang mendidik, dan (4) kemauan dan kemampuan untuk mengembangkan profesionalisme dan kepribadian secara berkelanjutan (DitnagaDIKTI, 2009).

Kinerja guru juga dapat dilihat dari rasa tanggung jawab menjalankan amanah, profesi dia akan memegang tanggung jawab moral.
Semua Ini akan terlihat dalam kepatuhan dan loyalitas dalam menjalankan tugas kependidikannya di kelas dan tugas di luar kelas. Sikap ini akan memberikan rasa mempersiapkan segala konsekuensinya mengajar untuk persediaan sebelum melaksanakan proses pembelajaran, termasuk metode, materi, media, serta teknik dan instrumen alat penilaian (Isjoni, 2004).

Ukuran lain kinerja guru adalah komitmennya untuk terus dan terus belajar, berinovasi, mengikuti perkembangan ilmu dan teknologi di era informasi dan globalisasi. Selain itu, pada kondisi kita sekarang dihadapkan pada era globalisasi, yang dinamis, dan kompetitif (Isjoni, 2004).

Beberapa indikator yang dirumuskan, setidaknya berkenaan dengan (1) keterampilan pedagogis - metodologis, (2) komunikasi, dan (3) yang berkaitan dengan pengembangan profesional lebih lanjut dari guru (Akhmad Sudrajad, 2008b).

Untuk penilaian kinerja guru secara teknis, Akhmad Sudrajad, (2008b) mengusulkan tiga langkah, yaitu (1) mengamati kelas (observasi Kelas), (2) memeriksa program kerja, khususnya RPP, dan (3) melakukan validasi data melalui triangulasi peneliti / estimator. kinerja profesional juga dapat dilihat dari aspek peningkatan kualitas (1) belajar dengan memberdayakan berbagai aspek sehingga guru meningkat kreativitas dan produktivitas. Kreativitas dan produktivitas mencapai lebar mendukung aspek persiapan belajar, dia belajar, metode, media, evaluasi, dan tindak lanjut; (2) penguasaan, aplikasi, dan produk Ilmu pengetahuan dan teknologi, seperti menulis buku, karya ilmiah, penelitian, membuat alat peraga, penerapan teknologi dalam aspek pembelajaran seperti media. Selain produk-produk teknologi yang dihasilkan juga dalam bentuk perangkat lunak dan perangkat keras. Dengan cara ini, unit produksi dapat dikembangkan berkontribusi sekolah, mengembangkan jiwa kewirausahaan, kerjasama, dan sebagainya; (3) kontribusi guru dalam pekerjaan yang dapat dieksploitasi orang lain. Guru dapat menyebarluaskan temuannya ke berbagai media sehingga stakeholder dapat bergabung dan mendapatkan keuntungan dari karya guru; (4) pelaksanaan strategi atau teknologi baru dalam belajar seperti elearning, lesson study, pembelajaran kuantum, konstruktivisme; (5) memanfaatkan teknologi informasi sebagai sarana pembelajaran seperti 
internet; dan (6) motivasi terus berkembang untuk kemajuan dan kualitas pembelajaran, administrasi, pengembangan diri, yang menyebabkan perbaikan dan peningkatan kualitas pembelajaran.

\section{PENUTUP}

Guru memiliki peran strategis dalam bidang pendidikan, bahkan sumber pendidikan lainnya adalah sering kurang memadai jika tidak didukung oleh kehadiran seorang guru yang berkualifikasi. Dengan kata lain, guru adalah kunci utama dalam upaya untuk meningkatkan mutu pendidikan. Hal ini juga ditekankan dalam undang-undang Republik Indonesia Nomor 20 Pada tahun 2003 tentang sistem pendidikan nasional, yang menyebutkan bahwa jabatan guru sebagai pendidik adalah jabatan professional sesuai dengan undangundang No. 14 tahun 2005. Untuk itu, guru profesional dituntut untuk terus mengembangkan diri sesuai dengan bidang ilmu, dan mengikuti perkembangan IPTEK, serta kebutuhan masyarakat termasuk kebutuhan sumber daya manusia yang berkualitas dan memiliki kemampuan untuk bersaing dalam forum regional, nasional, atau Internasional.

Dalam melakukan kewenangan profesionalismenya, guru dituntut memiliki seperangkat kemampuan (competency) yang beraneka ragam. Dalam Undang-Undang Guru dan Dosen No. 14 Tahun 2005 dan Peraturan Pemerintah No.19 Tahun 2005 dinyatakan bahwa kompetensi guru meliputi kompetensi kepribadian, kompetensi pedagogik, kompetensi profesional dan kompetensi sosial. Berlakunya undang-undang dan peraturan tersebut menuntut para guru untuk meningkatkan profesionalismenya melalui pelatihan, penulisan karya ilmiah, dan sebagainya.

\section{DAFTAR PUSTAKA}

Akhmad Sudrajad. (2008a). Manajemen Kinerja Guru. (http://akhmadsudrajat.wordpress. com/2008/02/03/manajemen-kinerja- guru/, diakses tanggal 27 Januari 2009).

Akhmad Sudrajad. (2008b). Konsep Penilaian Kinerja Guru. Online artikel. (http://akhmadsudrajat.wordpress.com/ 2008/11/21/konsep-penilaiankinerjaguru/, diakses tanggal 27 Januari 2009).

Ditjen DIKTI. (2008). Sertifikasi Guru dalam Jabatan Tahun 2008: Pedoman Sertifikasi Guru dalam Jabatan melalui Penilaian Potofolio. Jakarta: Ditjen DIKTI, Depdiknas.

Hasan, Ani M. (2008). Pengembangan Profesionalisme Guru di Abad Pengetahuan (http://researchengines.com/amhasan.html, diakses tanggal 16 Maret 2009). Isjoni. (2004). Kinerja Guru. Artikel online. (http://researchengines.com/isjoni12.html, diakses tanggal 27 Januari 2008).

Jatmiko, Wahyu. (2008). Pentingnya

Profesional Seorang Guru. (http://batampos.co .id/Opini/Opini/Pentingnya_Profesiona 1_Seorang_Guru. html, diakses tanggal 16 Maret 2009)

Peraturan Pemerintah RI Nomor 19 Tahun 2005, tentang Standar NasionalPendidikan.

Raka Joni, T. (2008). Model Pendidikan Guru dan Pendidikan Dosen, PraJabatan.Makalah disampaikan pada KONASPI tanggal 5 - 7 November 2008 diDenpasar.

Shukla Subir. (2008). Mulainya Sebuah Perjalanan: Peningkatan Kinerja Guru di India. (http://www.idpeurope.org/eenet/newsletter5_indonesi a/page24.php, diakses tanggal 27 Januari 2009) 